\title{
RELIGIUS CULTURE DALAM KOMUNITAS SEKOLAH
}

\author{
Siti Majidah \\ Dosen Tetap INAIFAS Kencong Jember \\ Jember/majidahsiti84@gmail.com
}

\begin{abstract}
Education contributes greatly to the progress of a nation and is a vehicle for translating constitutional messages and means in building national character (character building). An intelligent society will give a smart nuance of life and will progressively form independence. Schools as one of the educational institutions which are an expansion of the individual's social environment for the development of social relations capabilities and at the same time are new environmental factors that are very challenging or even worrying for him. This is because the factors of the situation or circumstances that affect the learning process in students related to the students themselves, the state of learning, the learning process, teachers who provide lessons, friends learn and get along, as well as learning programs taken. All of them are factors that are closely related to one another.
\end{abstract}

Keywords: Religious Culture, School Community.

\section{PENDAHULUAN}

Kehidupan modern, dengan kebudayaan yang semakin berubah dan pemenuhan berbagai mobilitas kehidupan secara teknologis-mekanis, satu sisi sangat berdampak positif, pada sisi lain tidak dapat dihindari dampak negatifnya, yang kemudian melahirkan krisis multidimensional di masyarakat. Ironi, karena tidak hanya terjadi pada lapisan bawah, tetapi juga meracuni atmosfir birokrasi negara mulai dari level paling atas sampai paling bawah. Dari kalangan tua, muda, bahkan anak-anak telah dilanda. Tidak hanya krisis sosial saja, tetapi sudah tidak terhitung yang merambah kepada tindak kriminalitas.

Realitas di atas mendorong timbulnya berbagai gugatan terhadap efektivitas pendidikan agama yang selama ini dipandang oleh sebagian besar masyarakat telah gagal dalam membangun afeksi peserta didik dengan nilai-nilai yang eternal dan mampu menjawab tantangan jaman yang terus berubah. Terlebih lagi dalam hal ini dunia pendidikan juga mengemban peran sebagai pusat pengembangan ilmu dan sumber daya manusia, pusat penelitian dan sekaligus pusat kebudayaan, kurang berhasil jika tidak dikatakan gagal dalam mengemban misinya. Sistem pendidikan yang dikembangkan selama ini lebih mengarah kepada pengisian

FALASIFA, Vol. 9 Nomor 1 Maret 2018 | 49 
Siti Majidah

kognitif peserta didik un-sich, sehingga melahirkan lulusan yang cerdas tetapi kurang bermoral. ${ }^{1}$ Aspek afeksi dan psikomotor yang sangat vital keberadaannya terabaikan begitu saja.

Fenomena di atas tidak terlepas dari adanya pemahaman yang kurang benar tentang agama dan keberagamaan (religiusitas). Agama sering kali dimaknai secara dangkal, tekstual dan cenderung esklusif. Nilai-nilai agama hanya dihapal sehingga hanya berhenti kepada wilayah kognisi, tidak sampai menyentuh aspek afeksi dan psikomotorik. Dalam hal ini yang mempunyai peran strategis adalah pendidikan. Pendidikan merupakan investasi dalam pengembangan sumber daya manusia karena peningkatan kecakapan dan kemampuan yang diyakini sebagai faktor pendukung upaya manusia dalam mengarungi kehidupan yang penuh dengan ketidakpastian. Dalam konteks inilah pendidikan diperlukan dan dipandang sebagai kebutuhan dasar bagi masyarakat yang ingin maju, demikian juga bagi masyarakat Indonesia yang memiliki wilayah yang sangat luas. ${ }^{2}$

Pendidikan memberikan kontribusi yang sangat besar terhadap kemajuan suatu bangsa dan merupakan wahana dalam menerjemahkan pesan-pesan konstitusi serta sarana dalam membangun watak bangsa (character building). Masyarakat yang cerdas akan memberikan nuansa kehidupan yang cerdas pula dan secara progresif akan membentuk kemandirian. Masyarakat bangsa yang demikian merupakan investasi besar untuk berjuang ke luar dari krisis dan menghadapi dunia global. ${ }^{3}$ Sekolah adalah lembaga pendidikan yang merupakan perluasan lingkungan sosial individu untuk pengembangan kemampuan hubungan sosialnya dan sekaligus merupakan faktor lingkungan baru yang sangat menantang atau bahkan mencemaskan bagi dirinya. Para guru dan teman-teman sekelas membentuk suatu sistem yang kemudian menjadi seolah lingkungan norma baru. ${ }^{4}$

Faktor situasi atau keadaan yang mempengaruhi proses belajar pada siswa berkaitan dengan diri siswa sendiri, keadaan belajar, proses belajar, guru yang memberikan pelajaran, teman belajar dan bergaul, serta program belajar yang ditempuh, merupakan faktor yang memiliki pertalian erat satu dengan lainnya. Itu semua merupakan komponen keadaan (situasi) belajar yang menjadi salah satu faktor penting dalam belajar. ${ }^{5}$

${ }^{12}$ A. Qodri Azizy, Pendidikan (Agama) untuk Membangun Etika Sosial (Semarang : Aneka Ilmu, 2002), 8-14.

${ }^{2}$ Mulyasa, Manajemen Berbasis Sekolah (Bandung : Remaja Rosdakarya, 2007), iii.

${ }^{3}$ Ibid, 4.

${ }^{4}$ Muhammad Asrori, Psikologi Pembelajaran (Bandung : Wacana Prima, 2007), 115.

${ }^{5}$ Sumiati Asra, Metode Pembelajaran (Bandung : CV. Wacana Prima, 2007), 60

50| FALASIFA, Vol. 9 Nomor 1 Maret 2018 


\section{PEMBAHASAN}

\section{Budaya Religius (Religions Culture)}

Pendidikan agama merupakan syarat pembentukan nilai-nilai moral (pembentukan afeksi), menurut Mochtar Buchori juga hanya memperhatikan aspek kognitif semata dari pertumbuhan kesadaran nilai-nilai (agama), dan mengabaikan pembinaan aspek afektif dan konatif-volitif, yakni kemauan dan tekad untuk mengamalkan nilai-nilai ajaran agama. ${ }^{6}$ Pengajaran agama yang berorientasi kognitif semata, hanyalah sekedar pengalihan pengetahuan tentang agama. Pengalihan pengetahuan agama memang dapat menghasilkan pengetahuan dan ilmu dalam diri orang yang diajar, tetapi pengetahuan ini belum menjamin pengarahan seseorang untuk hidup sesuai dengan pengetahuan tersebut. Bahkan, pengalihan pengetahuan agama sering kali berbentuk pengalihan rumus-rumus doktrin dan kaidah susila. Oleh sebab itu, pengajaran agama menghasilkan pengetahuan hafalan yang melekat di bibir dan hanya mewarnai kulit, tetapi tidak mampu mempengaruhi orang yang mempelajarinya. ${ }^{7}$

Istilah budaya pada awalnya berasal dari disiplin ilmu antropologi sosial dan memiliki cakupan yang sangat luas. Istilah budaya dapat diartikan sebagai totalitas pola perilaku, kesenian, kepercayaan, kelembagaan dan semua produk lain dari karya dan pemikiran manusia yang mencirikan kondisi suatu masyarakat atau penduduk yang ditransmisikan bersama. ${ }^{8}$ istiadat, sesuatu yang sudah berkembang, sesuatu yang menjadi kebiasaan yang sukar untuk diubah. ${ }^{9}$ Dalam pemakaian sehari-hari, orang biasanya menyamakan pengertian budaya dengan tradisi (tradition). Dalam hal ini, tradisi diartikan sebagai ide-ide umum, sikap dan kebiasaan dari masyarakat yang nampak dari perilaku sehari-hari dan menjadi kebiasaan dari kelompok dalam masyarakat tersebut. ${ }^{10}$

Tylor mengartikan budaya sebagai that complex whole which includes knowledge, beliefs, art, morals, laws, customs and other capabilities and habits acquired by man as a member of society. Budaya merupakan suatu kesatuan yang unik dan

${ }^{6}$ Muhaimin, Pengembangan Kurikulum Pendidikan Agama Islam; di Sekolah. Madrasah, dan Perguruan Tinggi (Jakarta: Raja Grafindo Persada, 2010), hlm. 23.

${ }^{7}$ J. Riberu, Pendidikan Agama dan Tata Nilai, dalam Sindhunata (Editor), Pendidik an; Kegelisahan Sepanjang Zaman (Yogyakarta: Kanisius, 2001), hlm. 190.

${ }^{8}$ J.P. Kotter \& J.L. Heskett, Dampak Budaya Perusabaan Terbadap Kinerja, terj. Benyamin Molan (Jakarta Prenhallindo, 1992), 4.

${ }^{9}$ Departemen Pendidikan dan Kebudayaan, Kamus Besar Bahasa Indonesia (Jakarta : PT. Balai Pustaka, 1991),149

10 Soekarto Indrafchrudi, Bagaimana Mengakrabkan Sekolah dengan Orangtua Murid dan Masyarakat (Malang : IKIP Malang, 1994), 20.

FaLASIFA, Vol. 9 Nomor 1 Maret $2018 \mid 51$ 
bukan jumlah dari bagian-bagian suatu kemampuan kreasi manusia yang immaterial, berbentuk kemampuan psikologis seperti ilmu pengetahuan, teknologi, kepercayaan, keyakinan, seni dan sebagainya. ${ }^{11}$

Koentjaraningrat mengelompokkan aspek-aspek budaya berdasarkan dimensi wujudnya, yaitu (1) kumpulan gugusan atau ide seperti pikiran, pengetahuan, nilai, keyakinan, norma dan sikap (2) kumpulan aktivitas seperti pola komunikasi, tari-tarian dan upacara adat ${ }^{12}$ (3) material hasil benda seperti seni, peralatan dan lain sebagainya. Sedangkan menurut Robert K. Marton, di antara segenap unsur-unsur budaya terdapat unsur yang terpenting, yaitu kerangka aspirasi tersebut, dalam artian ada nilai budaya yang merupakan konsepsi abstrak dan hidup di dalam alam pikiran ${ }^{13}$

Proses pembentukan budaya terdiri dari sub-proses yang saling berhubungan antara lain: kontak budaya, penggalian budaya, seleksi budaya, pemantapan budaya, sosialisasi budaya, internalisasi budaya, perubahan budaya, pewarisan budaya yang terjadi dalam hubungannya dengan lingkungannya secara terus menerus dan berkesinambungan. ${ }^{14}$

Budaya itu paling sedikit mempunyai tiga wujud, yaitu kebudayaan sebagai 1) suatu kompleks ide-ide, gagasan nilai-nilai, norma-norma, peraturan dan sebagainya, 2) suatu kompleks aktivitas kelakukan dari manusia dalam masyarakat, dan 3) sebagai benda-benda karya manusia. ${ }^{15}$ Religius biasa diartikan dengan kata agama. Agama menurut Frazer, sebagaimana dikutip Nuruddin, adalah sistem kepercayaan yang senantiasa mengalami perubahan dan perkembangan sesuai dengan tingkat kognisi seseorang. ${ }^{16}$ Sementara menurut Clifford Geertz, sebagaimana dikutip Roibin, agama bukan hanya masalah spirit, melainkan telah terjadi hubungan intens antara agama sebagai sumber nilai dan agama sebagai

11 Asri Budiningsih, Pembelajaran Moral Berpijak pada Karakteristik Siswa dan Budayanya (Jakarta : RinekaCipta, 2004), 18

${ }^{12}$ Koentjaraningrat, Rintangan-rintangan Mental dalam Pembangunan Ekonomi di Indonesia (Jakarta Lembaga Riset Kebudayaan Nasional Seni, 1969), 17.

${ }^{13}$ Fernandez S.0, Citra Manusia Budaya Timur dan Barat (Kupang : Nusa Indah, 1990), 28.

${ }^{14}$ Asmaun Sahlan, Mewrijudkan Budaya Religius di Sekolah: Upaya Mengembangkan PAI dari teori ke Aksi, (Malang: UIN Maliki Press, 2010),hlm. 72

${ }^{15}$ Madyo Ekosusilo, Hasil Penelitian Kualitatif Sekolah Unggul Berbasis Nilai: Studi Multi Kasus di SMAN 1, SMA Regina Pacis, dan SMA al-Islam 01 Surakarta, (Sukoharjo: UNIVET Bantara Press, 2003), hlm. 10

${ }^{16}$ Nuruddin, dkk, Agama Tradisional: Potret Kearifan Hidup Masyarakat Samin dan Tengger, (Yogyakarta: LKIS, 2003), hlm. 126

52| FALASIFA, Vol. 9 Nomor 1 Maret 2018 
sumber kognitif. Pertama, agama merupakan pola bagi tindakan manusia (pattern for behaviour). Dalam hal ini agama menjadi pedoman yang mengarahkan tindakan manusia. Kedua, agama merupakan pola dari tindakan manusia (pattern of behaviour). Dalam hal ini agama dianggap sebagai hasil dari pengetahuan dan pengalaman manusia yang tidak jarang telah melembaga menjadi kekuatan mistis. ${ }^{17}$

Agama dalam perspektif yang kedua ini sering dipahami sebagai bagian dari sistem kebudayaan, ${ }^{18}$ yang tingkat efektifitas fungsi ajarannya kadang tidak kalah dengan agama formal. Namun agama merupakan sumber nilai yang tetap harus dipertahankan aspek otentitasnya. Jadi di satu sisi, agama dipahami sebagai hasil menghasilkan dan berinteraksi dengan budaya. Pada sisi lain, agama juga tampil sebagai sistem nilai yang mengarahkan bagaimana manusia berperilaku.

\section{Pengembangan Budaya Agama (Religious Culture) dalam Komunitas Sekolah}

Pengembangan budaya agama dalam komunitas madrasah/ sekolah berarti bagaimana mengembangkan agama islam di madrasah sebagai pijakan nilai, semangat, sikap, dan perilaku bagi para aktormadrasah, guru dan tenaga kependidikan lainnya, orang tua murid, dan peserta didik itu sendiri ${ }^{19}$. Pelaksanaan budaya religius di sekolah mempunyai landasan kokoh yang normatif religius maupun konstitusional sehingga tidak ada alasan bagi sekolah untuk mengelak dari usaha tersebut .Oleh karena itu, penyelenggaraan pendidikan agama yang diwujudkan dalam membangun budaya religius di berbagai jenjang pendidikan, patut untuk dilaksanakan. Karena dengan tertanamnya nilai-nilai budaya religius pada diri siswa akan memperkokok imannya dan aplikasinya nilainilai keislaman tersebut dapat tercipta dari lingkungan di sekolah. Untuk itu membangun budaya religius sangat penting dan akan mempengaruhi sikap, sifat dan tindakan siswa secara tidak langsung ${ }^{20}$

Pendidikan agama di sekolah, tidak saja di madrasah atau di sekolah yang bernuansa islami tetapi juga di sekolah-sekolah umum sangatlah penting

17 Roibin, Relasi Agama \& Budaya Masyarakat Kontemporer, Mlg: UIN Maliki Press, 2009, hlm. 75

${ }^{18}$ Nursyam, Islam Pesisir, (Yogyakarta: LKIS, 2005), hlm. 1

${ }^{19}$ Muhaimin, Pemikiran dan Aktualisasi Pengembangan Pendidikan Islam (Jakarta: Rajawali Pers, 2008), hlm. 133

20 Muhaimin,. Arah Barn Pengembangan Pendidikan Islam Pemberdayaan, Pengembangan Kurikulum Hingga Redifinisi Islamisasi Pengetahuan (Bandung: 2003), hlm. 23. 
untukpembinaan dan penyempurnaan pertumbuhan kepribadian anak didik, karenapendidikan agama melatih anak didik untuk melakukan ibadah yang diajarkandalam agama, yaitu praktek-praktek agama yang menghubungkan manusia denganTuhannya. Karena praktek-praktek ibadah itulah yang akan membawa jiwa anakkepada Tuhannya. Semakin sering dilakukan ibadah, semakin tertanamkepercayaan dan semakin dekat pula jiwa sang anak terhadap Tuhannya. Disamping praktek ibadah, anak didik harus dibiasakan mengatur tingkah lakudan sopan santun baik terhadap orang tua yang lebih tua maupun terhadap sesamateman sebayannya. Kepercayaan kepada Tuhan tidak akan sempurna bila isiajaran-ajaran dari Tuhan tidak diketahui betul-betul. Anak didik harus ditunjukkan mana yang disuruh dan mana yang dilarang oleh Tuhannya.

Dari sekian nilai yang terkandung dalam sumber ajaran Islam, nilai yang fundamental adalah nilai tauhid. Ismail Raji al-Faruqi memformulasikan bahwa kerangka Islam berarti memuat teori-teori, metode, prinsip dan tujuan yang tunduk kepada esensi Islam, yaitu tauhid. ${ }^{21}$ Dengan demikian, dalam penyelenggaraan pendidikan agama Islam atau PAI harus mengacu kepada nilai fundamental tersebut. Nilai tersebut memberikan arah dan tujuan dalam proses pendidikan serta memberikan motivasi dalam aktivitas pendidikan. ${ }^{21}$ Konsepsi tujuan pendidikan yang mendasarkan kepada nilai tauhid menurut al-Nahlawi disebut andaf al-rabbani, yaitu tujuan yang bersifat ketuhanan dan seharusnya menjadi dasar dalam kerangka berpikir, bertindak dan pandangan hidup dalam semua sistem serta aktivitas pendidikan.

Berkaitan dengan hal tersebut, budaya religius sekolah merupakan cara berpikir dan cara bertindak warga sekolah yang didasarkan atas nilai-nilai religius (keberagamaan). Religius menurut Islam adalah melaksanakan ajaran agama secara menyeluruh. Allah berfiman dalam QS. al-Baqarah ayat 208 sebagai berikut

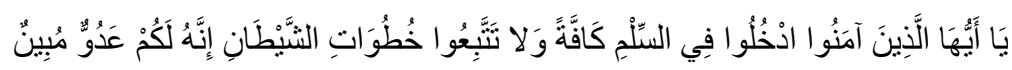

Artinya: Hai orang-orang yang beriman, masuklah kamu ke dalam Islam secara keselumban dan janganlah kamu turuti langkah-langkah setan. Sesunggubnya setan itu musuh yang nyata bagimu.

${ }^{21}$ Ismail Raji al-Faruqi, Islamization of Knowledge: General Principles and Workplan (Washington DC : International Institute of Islamic Thoungt, 1982), 34-36.

54 | FalASIFA, Vol. 9 Nomor 1 Maret 2018 
Menurut Glock dan Stark, sebagaimana dikutip Muhaimin, terdapat lima macam dimensi keberagamaan, yaitu:

1. Dimensi keyakinan yang berisi pengharapan-pengharapan, yang menyebabkan orang religius berpegang teguh kepada pandangan teologis tertentu dan mengakui keberadaan doktrin tersebut.

2. Dimensi praktik agama yang mencakup perilaku pemujaan, ketaatan dan halhal yang dilakukan orang untuk menunjukkan komitmen terhadap agama yang dianutnya.

3. Dimensi pengalaman yang berisikan perhatian kepada fakta bahwa semua agama mengandung pengharapan-pengharapan tertentu.

4. Dimensi pengetahuan agama yang mengacu kepada harapan bahwa orangorang yang beragama paling tidak memiliki sejumlah minimal pengetahuan mengenai dasar-dasar keyakinan, ritus-ritus, kitab suci dan tradisi.

5. Dimensi pengamalan atau konsekuensi yang mengacu kepada identifikasi akibat-akibat keyakinan keagamaan, praktik, pengalaman dan pengetahuan seseorang dari hari ke hari. ${ }^{22}$

Tradisi dan perwujudan ajaran agama memiliki keterkaitan yang erat, karena itu tradisi tidak dapat dipisahkan begitu saja dari masyarakat atau lembaga tempatnya dipertahankan, sedangkan masyarakat juga memiliki hubungan timbak balik, bahkan saling mempengaruhi dengan agama. Untuk itu, menurut Mukti Ali, agama mempengaruhi perjalanan masyarakat dan pertumbuhan masyarakat mempengaruhi pemikiran terhadap agama. Dalam kaitan ini, Sudjatmoko juga menyatakan bahwa keberagamaan manusia, pada saat yang bersamaan, selalu disertai dengan identitas budayanya masing-masing yang berbeda-beda. ${ }^{23}$

\section{Landasan Penciptaan Budaya Religius}

1. Landasan Agama

Penciptaan budaya religius yang dilakukan di sekolah semata-mata karena merupakan pengembangan dari potensi manusia yang ada sejak lahir atau fitrah. Ajaran Islam yang diturunkan Allah melalui rasul-Nya merupakan agama yang memperhatikan fitrah manusia, maka dari itu pendidikan Islam juga harus sesuai dengan fitrah manusia dan bertugas mengembangkan fitrah tersebut. Secara etimologis, kata fitrah yang berasal dari berarti "ciptaan" atau "penciptaan". Disamping itu, kata fiţrah juga berarti sebagai "sifat dasar atau pembawaan", berarti pula potensi dasar yang alami atau natural

$22{ }^{2}$ Muhaimin, Paradigma Pendidikan Islam (Bandung : Rosdakarya, 2001),294.

${ }^{23} \mathrm{Ibid}$

FALASIFA, Vol. 9 Nomor 1 Maret 2018 | 55 
disposition. Dengan demikian fitrah adalah sifat dasar atau potensi pembawaan yang diciptaan oleh Allah sebagai dasar dari suatu proses penciptaan. Kata fitrah tersebut diisyaratkan dalam firman Allah SWT, sebagai berikut:

Artinya: Maka hadapkanlah wajahmu dengan lurus kepada agama Allah; (tetaplah atas) fitrah Allah yang Telah menciptakan manusia menurut fitrah itu. Tidak ada perubahan pada fitrah Allah. (Itulah) agama yang lurus tetapi kebanyakan manusia tidak mengetahui. (Q.S.Al-Rum/30:30).

Oleh karena itu fitrah manusia dapat dikembangkan melalui budaya religius yang diciptakan di sekolah. Sehingga penciptaan budaya religius yang ada di sekolah sesuai dengan pengembangan fitrah manusia.

2. Landasan Filosofis

Al-Ghazali berpendapat bahwa tujuan pendidikan Islam adalah membentuk insan purna yang pada akhirnya dapat mendekatkan diri kepada Allah. Sedangkan tujuan pendidikan adalah untuk mendekatkan diri kepada Allah, bukan untuk mencari kedudukan, kemegahan dan kegagahan ${ }^{24}$ atau mendapatkan kedudukan yang menghasilkan uang. Karena jika tujuan pendidikan diarahkan bukan mendekatkan diri pada Allah, akan dapat menimbulkan kedengkian, kebencian dan permusuhan. ${ }^{25}$ Di samping itu, tujuan pendidikan Islam adalah membentuk insan purna untuk memperoleh kebahagiaan hidup baik di dunia maupun di akhirat. Pendidikan itu tidak hanya bertujuan untuk memperoleh dunia saja, dan juga tidak hanya bertujuan untuk memperoleh akhirat saja, namun untuk memperoleh keduanya.

Berpijak dari pemikiran bahwa tujuan dari pendidikan agama Islam adalah untuk mensucikan jiwa, membentuk akhlak, menyiapkan seseorang dari segi keagamaan, bahkan membentuk insan yang kamil, maka diperlukan pengembangan lebih lanjut dalam pembelajaran pendidikan agama Islam sampai menyentuh pada aspek afektif dan psikomotorik melalui penciptaan budaya religius di sekolah, karena rata-rata pembelajaran pendidikan agama di sekolah hanya berpijak pada aspek kognitif saja dan kurang memperhatikan aspek afektif dan psikomotorik.

3. Landasan Yuridis

${ }^{24}$ Lihat Al-Ghazali, Bidayah al-Hidayah ...., hlm. 3. Bandingkan dengan Nuryani, "Wawasan Keilmuan Islam Al-Ghazali: Studi Analisa Pemikiran al-Ghazali dalam Kitab Bidayah al-Hidayah", dalam Ta'allum Jurnal Pendidikan Islam,Vol. 28, No.1, 37-38.

${ }^{25}$ Ahmad Tanzeh, Pendidikan Islam Dalam Perspektif Filosof Muslim, dalam Meniti Jalan Pendidikan Islam, ed, Akhyak, (Yogyakarta: Pustaka Pelajar, 2003),hlm. 117.

56| FALASIFA, Vol. 9 Nomor 1 Maret 2018 
Landasan yuridis dari penciptaan budaya religius adalah merujuk pada landasan keberadaan PAI dalam kurikulum sekolah, yaitu UU No. 20 tahun 2003, tentang Sisdiknas, Bab V pasal 12 ayat 1 point a, bahwasanya "Setiap siswa pada setiap satuan pendidikan berhak: mendapatkan pendidikan agama sesuai dengan agama yang dianutnya dan diajarkan oleh pendidik yang seagama”. Peningkatan iman dan taqwa serta akhlak yang mulia juga disebutkan dalam UU no 20 Tahun 2003 tentang Sisdiknas Bab X pasal 36 ayat 3, bahwasanya "Kurikulum disusun sesuai dengan jenjang pendidikan dalam kerangka Negara Kesatuan Republik Indonesia dengan memperhatikan peningkatan iman dan takwa, peningkatan akhlak mulia”. Dan pasal 37 ayat 1 , menyatakan bahwa "Kurikulum pendidikan dasar dan menengah wajib memuat: pendidikan agama”. Dalam PP 19 tahun 2005 pasal 6 ayat 1 juga dijelaskan Kurikulum untuk jenis pendidikan umum, kejuruan, dan khusus pada jenjang pendidikan dasar dan menengah terdiri atas: kelompok mata pelajaran agama dan akhlak mulia; kelompok mata pelajaran kewarganegaraan dan kepribadian; kelompok mata pelajaran ilmu pengetahuan dan teknologi; kelompok mata pelajaran estetika; kelompok mata pelajaran jasmani, olah raga, dan kesehatan.

Dari landasan yuridis tersebut sangat jelas bahwa pendidikan agama Islam merupakan salah satu mata pelajaran yang wajib ada di semua jenjang dan jalur pendidikan. Dengan demikian eksistensinya sangat strategis dalam usaha mencapai tujuan pendidikan nasional secara umum. Maka dari itu, penciptaan budaya religius sebagai upaya pengembangan pembelajaran pendidikan agama harus dilakukan.

4. Landasan Historis

Landasan historis ini diambil dari historisitas masuknya PAI di sekolah, karena budaya religius merupakan pengembangan dari pembelajaran pendidikan agama Islam di sekolah. Ketika pemerintah Sjahrir menyetujui pendirian Kementerian agama pada 3 Januari 1946, elit Muslim menempatkan agenda pendidikan menjadi salah satu agenda utama kementrian agama. Elit muslim melaksanakan dua upaya utama. Pertama, mengembangkan pendidikan agama (Islam) pada sekolah-sekolah umum yang sejak proklamasi berada di bawah pembinaan Kementrian PPK. Upaya ini meliputi: 1) memperjuangkan status pendidikan agama di sekolah-sekolah umum dan pendidikan tinggi, 2) mengembangkan kurikulum agama, 3) menyiapkan guru-guru agama yang berkualitas, 4) menyiapkan buku-buku pelajaran agama. Kedua, peningkatan kualitas atau modernisasi lembagalembaga pendidikan yang selama ini telah memberi perhatian pada 
pendidikan agama Islam dan pengetahuan umum modern sekaligus. Strateginya adalah: 1) dengan cara memperbaharui kurikulum yang ada dan memperkuat porsi kurikulum pengajaran umum modern sehingga tak terlalu ketinggalan dari sekolah- sekolah umum, 2) mengembangkan kualitas dan kuantitas guru-guru bidang studi umum, 3) menyediakan fasilitas belajar, seperti buku-buku bidang studi umum, dan 4) mendirikan sekolah kementrian agama di berbagai daerah sebagai percontohan.

Dari sejarah di atas, dapat dipahami bahwa salah satu perjuangan elit Muslim Indonesia di awal kemerdekaan adalah memperkokoh posisi pendidikan agama Islam di sekolah-sekolah umum sampai perguruan tinggi. Maka dari itu, hendaknya di era globalisasi sekarang ini, para praktisi pendidikan Islam hendaknya meningkatkan mutu pendidikan agama Islam dengan menciptakan dan mengembangkan budaya religius di sekolah.

5. Landasan Sosiologis

Landasan sosiologis penciptaan budaya religius adalah terdapatnya 2 macam tipe masyarakat. Pada dasarnya masyarakat dibagi menjadi masyarakat orde moral dan kerabat sentris. Pada tipe masyarakat orde moral komunitas kehidupan dan mekanismenya masih amat terikat oleh berbagai norma baik buruk yang bersumber dari tradisi sehingga disana banyak dijumpai pantangan yang dapat mengganggu penciptaan budaya religius. Sedangkan pada tipe masyarakat kerabat sentris, titik tekannya pada kekerabatan. Adat istiadat memang diwarisi secara turun temurun, namun ada kalanya adatistiadatnya diganti dengan yang lebih modernis. ${ }^{26}$ Masyarakat ini mendukung penciptaan budaya religius. Dari hal tersebut dapat dipahami bahwa budaya religius diciptakan di sekolah sebagai alat penggantian adat istiadat lama dengan adat istiadat modernis.

Di samping itu, penciptaan budaya religius di sekolah dapat mengakibatkan perubahan sikap sosial pada diri anak didik. Hal tersebut dikarenakan dengan adanya budaya religius di sekolah anak menjadi terinternalisasi nilai-nilai religius dan berusaha mengimplementasikannya dengan akhlak terpuji di kehidupan sehari-hari.

6. Landasan Psikologis

Menurut penelitian Muhaimin, dalam bukunya, kegiatan keagamaan seperti khatmil al-Qur'an dan istighatsah dapat menciptakan suasana ketenangan dan kedamaian di kalangan civitas akademika lembaga

${ }^{26}$ Muhaimin.et.all, Paradigma Pendidikan..., hlm. 288-289 
pendidikan. ${ }^{27}$ Maka dari itu, suatu lembaga pendidikan harus dan wajib mengembangkan budaya religius untuk menciptakan ketenangan dan ketentraman bagi orang yang ada di dalamnya.

Di samping itu, budaya religius juga merupakan sarana penyeimbangan kerja otak yang terbagi menjadi dua, kanan dan kiri. otak merupakan sekumpulan jaringan syaraf yang terdiri dari dua bagian yaitu otak kecil dan otak besar. Pada otak besar terdapat belahan yang memisahkan antara belahan kiri dan belahan otak kanan. Belahan ini dihubungkan dengan serabut saraf. Belahan kiri berfungsi untuk mengembangkan kemampuan berbicara, menulis, dan berhitung. Belahan kiri mengontrol kemampuan untuk menganilisis, sehingga berkembang kemampuan untuk berpikir secara sistimatis. Artinya dalam menyelesaikan sebuah persoalaan, belahan otak kiri akan bekerja berdasarkan fakta dan uraian yang sistimatis dan logis. Otak kiri berfungsi sebagai pengendali kecerdasan intelektual (IQ). Daya ingat otak kiri lebih bersifat jangka pendek (short term memory). Secara lebih luas otak kiri identik dengan rapi, perbedaan, angka, urutan, tulisan, bahasa, hitungan, logika, terstruktur, analitis, matematis, sistematis, linear, dan tahap demi tahap. Apabila terjadi kerusakan pada otak kiri maka akan terjadi gangguan dalam hal fungsi berbicara, berbahasa, dan matematika.

Sedangkan belahan otak kanan berfungsi untuk mengembangkan visual dan spasial (pemahaman ruang). Belahan ini bekerja berdasarkan datadata yang ada dalam pikiran baik berupa bentuk, suara atau gerakan. Belahan kanan lebih peka terhadap hal yang bersifat estetis dan emosi. Intinya otak kanan bekerja dengan lebih menekankan pada cara berpikir sintetis yaitu menyatukan bagian-bagian informasi yang ada untuk membentuk konsep utuh tanpa terikat pada langkah dan berstruktur. ${ }^{28}$ Otak kanan mengarah pada cara berpikir menyebar yang berfungsi dalam perkembangan kecerdasan emosional (emotional quotient, EQ) dan identik dengan kreativitas, persamaan, khayalan, bentuk atau ruang, emosi, musik, warna, berpikir lateral, tidak terstruktur, dan cenderung tidak memikirkan hal-hal yang terlalu mendetail. Ketika otak kanan sedang bekerja maka otak kiri cenderung lebih tenang, demikian pula sebaliknya. Daya ingat otak kanan bersifat panjang (long term memory). Bila terjadi penyakit stroke atau tumor otak, maka fungsi otak yang terganggu adalah kemampuan visual dan emosi.

${ }^{27}$ Muhaimin.et.all, Paradigma Pendidikan..., hlm. 299-300

${ }^{28}$ Yuliani Nurani Sujiono, Konsep Dasar Pendidikan Siswa Usia Dini ( Jakarta: Indeks, 2009), hlm. 182.

FALASIFA, Vol. 9 Nomor 1 Maret 2018 | 59 
Berpijak dari teori belahan otak di atas, budaya religius dapat digunakan sebagai media pembelajaran PAI yang prinsipnya bisa langsung aplikasi atau dalam ranah afektif dan psikomotorik, sehingga hal tersebut bisa mempekerjakan otak kanan. Maka, dengan adanya budaya religius di sekolah, otak kanan dan otak kiri mampu bekerja secara bersamasama, sehingga pada akhirnya perkembangannya menjadi baik.

7. Landasan Kultural

Para ahli pendidikan dan antropologi sepakat bahwa budaya adalah dasar terbentuknya kepribadian manusia. Dari budaya dapat terbentuk identitas seseorang, identitas masyarakat bahkan identitas lembaga pendidikan. Di lembaga pendidikan secara umum terlihat adanya budaya yang sangat melekat dalam tatanan pelaksanaan pendidikan yang menjadikan inovasi pendidikan sangat cepat, budaya tersebut berupa nilainilai religius, filsafat, etika dan estetika yang terus dilakukan.

Budaya sekolah dapat berupa suatu kompleks ide-ide, gagasan nilainilai, norma- norma, peraturan dan sebagainya, aktivitas kelakukan dari manusia dalam lembaga pendidikan, dan benda-benda karya manusia. Budaya yang terjadi di lembaga pendidikan, termasuk di dalamnya adalah budaya religius, merupakan bidang budaya organisasi (organizational culture).

Robbins menegaskan bahwa budaya organisasi adalah suatu persepsi bersama yang dianut oleh anggota-anggota organisasi itu, suatu sistem dari makna bersama. ${ }^{29}$ Dari pengertian budaya dan organisasi baik secara umum maupun secara khusus dan begitu juga dari definisi budaya organisasi di atas, maka penulis menyimpulkan bahwa budaya organisasi ialah, sistem nilai, norma, atau aturan, falsafah, kepercayan dan sikap (perilaku) yang dianut bersama para anggota yang berpengaruh terhadap pola kerja serta pola manajemen organisasi.

8. Landasan Ekonomi

Dari segi ekonomi, penciptaan budaya religius di sekolah akan menambah kompetensi siswa dalam mengimplementasikan agama Islam dalam kehidupan sehari-hari. Tentu saja hal ini menimbulkan dampak positif dalam segi ekonomi siswa. Dalam arti jika ia mampu untuk mengembangkan apa yang telah dilakukan terlebih dahulu di sekolah, maka ia akan menjadi dai yang mampu untuk diandalkan dan hal itu bisa menambah segi ekonomi tersendiri. Selain itu, lembaga pun juga terkena dampak dalam aspek

29 Stephen P. Robbins, Organisasi theory, Structure Design, And Aplication, (Inc Rangeewood Cliff: Prentice Hall, 1990), 289.

$60 \mid$ FalASIFA, Vol. 9 Nomor 1 Maret 2018 
ekonomi ini. Yaitu apabila lembaga mengembangkan kewirausahaan yang sesuai dengan budaya serta nilai yang dikembangkan, maka lembaga pendidikan tersebut akan mendapat untung yang cukup menggembirakan.

\section{Budaya Agama}

Berdasarkan konsep diatas, penulis memahami kebudayaan merupakan suatu prestasi hasil kreasi manusia yang bersifat immaterial. artinya berupa bentukbentuk prestasi psikologis seperti ilmu pengetahuan, kepercayaan, seni dan lain sebagainya. Agar budaya tersebut menjadi nilai-nilai yang langgeng, maka harus ada proses internalisasi budaya. Internalisasi adalah proses menanamkan dan menumbuhkembangkan suatu nilai atau budaya menjadi bagian diri (self) orang yang bersangkutan. Penanaman dan penumbuhkembangan nilai tersebut dilakukan melalui berbagai didaktik metodik pendidikan dan pengajaran. ${ }^{30}$

Dengan demikian, budaya religius sekolah adalah upaya terwujudnya nilainilai ajaran agama sebagai tradisi dalam berperilaku dan budaya organisasi yang diikuti oleh seluruh warga di sekolah tersebut. Dengan menjadikan agama sebagai tradisi dalam sekolah maka secara sadar maupun tidak ketika warga sekolah mengikuti tradisi yang telah tertanam tersebut sebenarnya warga sekolah sudah melakukan ajaran agama. Pembudayaan nilai-nilai keberagamaan (religius) dapat dilakukan dengan beberapa cara, antara lain melalui: kebijakan pimpinan sekolah, pelaksanaan kegiatan belajar mengajar di kelas, kegiatan ekstra kurikuler, serta tradisi dan perilaku warga sekolah secara konsisten, sehingga tercipta religious culture dalam lingkungan lembaga pendidikan.

Sedangkan Kegiatan-kegiatan yang dapat menumbuhkan budaya religius (religious culture) di lingkungan sangat variatif. Melakukan kegiatan rutin, yaitu upaya pengembangan kebudayaan religius secara rutin berlangsung pada hari-hari belajar biasa di lembaga pendidikan. Kegiatan rutin ini dilakukan dalam kegiatan sehari-hari yang terintegrasi dengan kegiatan yang telah diprogramkan, sehingga tidak memerlukan waktu khusus. Pendidikan agama tidak hanya terbatas pada aspek pengetahuan, tetapi juga meliputi pembentukan sikap, perilaku, dan pengalaman keagamaan. Untuk itu pembentukan sikap, perilaku, dan pengalaman keagamaan pun tidak hanya dilakukan oleh guru agama, tetapi perlu didukung oleh guru-guru bidang studi lainnya.

Guru dapat memberikan pendidikan agama secara spontan ketika menghadapi sikap atau perilaku peserta didik yang tidak sesuai dengan ajaran agama. Manfaat pendidikan secara spontan ini menjadikan siswa langsung

${ }^{30}$ Talizhidu Ndraha, Budaya Organisasi, (Jakarta: Rineka Cipta, 1997), hlm. 82

FALASIFA, Vol. 9 Nomor 1 Maret 2018 | 61 
mengetahui dan menyadari kesalahan yang dilakukannya dan langsung pula mampu memperbaikinya. Manfaat lainnya dapat dijadikan pelajaran atau hikmah oleh siswa lainnya, jika perbuatan salah jangan ditiru, sebaliknya jika ada perbuatan yang baik harus ditiru.

Menciptakan lingkungan dan situasi religius. Tujuannya untuk mengenalkan kepada siswa tentang pengertian agama dan tata cara pelaksanaan agama tersebut dalam kehidupan sehari-hari. Menunjukkan pengembangan kehidupan religius di lembaga pendidikan yang tergambar dari perilaku sehari-hari dari berbagai kegiatan yang dilakukan oleh guru dan siswa. Selain itu dengan menciptakan suasana kehidupan keagamaan di sekolah antara sesama guru, guru dengan siswa, atau siswa dengan siswa lainnya. Misalnya, dengan mengucapkan kata-kata yang baik ketika bertemu atau berpisah, mengawali dan mengakhiri suatu kegiatan, mengajukan pendapatan atau pertanyaan dengan cara yang baik, sopan, santun tidak merendahkan siswa lainnya, dan sebagainya.

Memberikan kesempatan kepada siswa sekolah/madrasah untuk mengekspresikan diri, menumbuhkan bakat, minat dan kreativitas pendidikan agama dalam keterampilan dan seni, seperti membaca al-Quran, adzan, sari tilawah, serta untuk mendorong siswa sekolah mencintai kitab suci, dan meningkatkan minat siswa untuk membaca, menulis serta mempelajari isi kandungan al-Quran. Dalam membahas suatu materi pelajaran agar lebih jelas guru hendaknya selalu diperkuat oleh nas-nas keagamaan yang sesuai berlandaskan pada al-Quran dan Hadits Rasulullah SAW. Tidak hanya ketika mengajar saja tetapi dalam setiap kesempatan guru harus mengembangkan kesadaran beragama dan menanamkan jiwa keberagamaan yang benar. Guru memperhatikan minat keberagaman siswa. Untuk itu guru harus mampu menciptakan dan memanfaatkan suasana keberagamaan dengan menciptakan suasana dalam peribadatan seperti shalat, puasa dan lain-lain.

Saat ini, usaha penanaman nilai-nilai religius untuk mewujudkan budaya religius sekolah dihadapkan kepada berbagai tantangan, baik secara internal maupun eksternal. Secara internal, pendidikan dihadapkan kepada keberagaman siswa, baik dari sisi keyakinan beragama maupun keyakinan dalam satu agama. Lebih dari itu, setiap siswa memiliki latar belakang kehidupan yang berbeda-beda. Oleh karena itu, pembelajaran agama diharapkan menerapkan prinsip-prinsip keberagaman sebagai berikut :

\section{Belajar Hidup dalam Perbedaan}

Perilaku-perilaku yang diturunkan ataupun ditularkan oleh orang tua kepada anaknya atau oleh leluhur kepada generasinya sangat dipengaruhi oleh kepercayaan-kepercayaan dan nilai budaya, selama beberapa waktu akan 
terbentuk perilaku budaya yang meresapkan citra rasa dari rutinitas, tradisi, bahasa, kebudayaan, identitas etnik, nasionalitas dan ras.

Berbagai perilaku ini akan dibawa oleh anak-anak ke sekolah dan setiap siswa memiliki perbedaan latar belakang sesuai daerah asal mereka. Keragaman ini menjadi pusat perhatian dari pendidikan agama Islam berwawasan multikultural. Jika pendidikan agama Islam selama ini masih konvensional dengan lebih menekankan kepada proses how to know, how to do dan how to be, maka pendidikan agama Islam berwawasan multikultural menambahkan proses how to live and work together with other yang ditanamkan oleh praktik pendidikan, melalui :

a) Pengembangan sikap toleransi, empati dan simpati yang merupakan prasyarat

esensial bagi keberhasilan ko-eksistensi dan pro-eksistensi dalam keragaman

agama. PAI dirancang untuk menanamkan sikap toleran dari tahap yang paling sederhana sampai beragam.

b) Klarifikasi nilai-nilai kehidupan bersama menurut perspektif anggota dari masing-masing kelompok yang berbeda. PAI harus mampu menjembatani perbedaan yang ada di dalarn masyarakat, sehingga perbedaan tidak menjadi halangan yang berarti dalam membangun kehidupan bersama yang bahagia dan sejahtera.

c) Pendewasaan emosional, kebersamaan dalam perbedaan membutuhkan kebebasan dan keterbukaan. Kebersamaan, kebebabasan dan keterbukaan harus tumbuh bersama menuju pendewasaan emosional dalam relasi antar dan intra agama-agama.

d) Kesetaraan dalam partisipasi. Perbedaan yang ada pada nafsu hubungan harus diletakkan kepada relasi dan kesalingtergantungan. Oleh karena itu, mereka bersifat setara. Perlu disadari bahwa setiap individu memiliki kesempatan untuk hidup dan memberikan kontribusi bagi kesejahteraan manusia yang universal.

e) Kontrak sosial dan aturan main kehidupan bersama. Dipandang perlu PAI memberikan bekal tentang keterampilan dalam berkomunikasi, yang sesungguhnya sudah termuat dalam nilai-nilai agama Islam.

\section{Membangun Saling Percaya (Mutual Trust)}

Saling percaya merupakan faktor yang sangat penting dalam sebuah hubungan. Disadari atau tidak, prasangka dan kecurigaan yang berlebih terhadap kelompok lain telah diturunkan dari satu generasi ke generasi 
berikutnya. Hal ini yang membuat kehati-hatian dalam melakukan kontrak, transaksi, hubungan dan komunikasi dengan orang lain, yang justeru memperkuat intensitas kecurigaan yang dapat mengarah kepada ketegangan dan konflik. Maka dari itu, PAI memiliki tugas untuk menanamkan rasa saling percaya antar agama, antar kultur dan antar etnik, meskipun masing-masing memiliki perbedaan.

\section{Memelibara Saling Pengertian (Mutual Understanding)}

Saling mengerti berarti saling memahami. Perlu diluruskan bahwa memahami tidak serta merta disimpulkan sebagai tindakan menyetujui, akan tetapi memahami berarti menyadari bahwa nilai-nilai mereka dan dapat saling berbeda, bahkan mungkin saling melengkapi dan memberikan kontribusi terhadap relasi yang dinamis dan hidup. PAI berwawasan multikultural memiliki tanggung jawab dalam membangun landasan-landasan etis saling kesepahaman antara paham-paham intern agama, antar entitas-entitas agama dan budaya yang plural, sebagai sikap dan kepedulian terhadap sesama.

\section{Strategi Penciptaan Budaya Religius di Sekolah}

Langkah nyata untuk mewujudkan budaya religius di lembaga pendidikan, menurut Koentjaraningrat, ialah upaya pengembangan dalam tiga tataran, yaitu 1) tataran nilai yang dianut, 2) tataran praktik keseharian, 3) dan tataran simbol-simbol budaya. ${ }^{31}$ Pada tataran nilai yang dianut, perlu dirumuskan secara bersama nilai-nilai agama yang disepakati dan perlu dikembangkan di lembaga pendidikan, untuk selanjutnya membangun komitmen dan loyalitas bersama diantara semua anggota lembaga pendidikan terhadap nilai yang disepakati. Pada tahap ini diperlukan juga konsistensi untuk menjalankan nilai-nilai yang telah disepakati tersebut dan membutuhkan kompetensi orang yang merumuskan nilai guna memberikan contoh bagaimana mengaplikasikan dan memanifestasikan nilai dalam kegiatan sehari-hari.

Dalam tataran praktik keseharian, nilai-nilai religius yang telah disepakati tersebut diwujudkan dalam bentuk sikap dan perilaku keseharian oleh semua warga sekolah. Proses pengembangan tersebut dapat dilakukan melalui tiga tahap, yaitu: pertama, sosialisasi nilai-nilai religius yang disepakati sebagai

31 Koentjaraningrat "Kebudayaan, Mentalitas dan Pembangunan" dalam Muhaimin, Nuansa Baru Pendidikan Islam, (Jakarta: Raja Grafindo Persada, 2006), hlm. 157.

64 | FalasIFA, Vol. 9 Nomor 1 Maret 2018 
sikap dan perilaku ideal yang ingin dicapai pada masa mendatang di lembaga pendidikan. Kedua, penetapan action plan mingguan atau bulanan sebagai tahapan dan langkah sistematis yang akan dilakukan oleh semua pihak di lembaga pendidikan yang mewujudkan nilai-nilai religius yang telah disepakati tersebut. Ketiga, pemberian penghargaan terhadap prestasi warga lembaga pendidikan, seperti guru, tenaga kependidikan, dan siswa sebagai usaha pembiasaan (babit formation) yang menjunjung sikap dan perilaku yang komitmen dan loyal terhadap ajaran dan nilai-nilai religius yang disepakati. Penghargaan tidak selalu berarti materi (ekonomik), melainkan juga dalam arti sosial, cultural, psikologis ataupun lainnya.

Dalam tataran simbol-simbol budaya, pengembangan yang perlu dilakukan adalah mengganti simbol-simbol budaya yang kurang sejalan dengan ajaran dan nilai- nilai agama dengan simbol budaya yang agamis. Perubahan simbol dapat dilakukan dengan mengubah model berpakaian dengan prinsip menutup aurat, pemasangan hasil karya siswa, foto-foto dan motto yang mengandung pesan-pesan nilai keagamaan.

Strategi untuk membudayakan nilai-nilai religius di lembaga pendidikan dapat dilakukan melalui: (1) power strategi, yakni strategi pembudayaan agama di lembaga pendidikan dengan cara menggunakan kekuasaan atau melalui people's power, dalam hal ini peran kepala lembaga pendidikan dengan segala kekuasaannya sangat dominan dalam melakukan perubahan; (2) persuasive strategy, yang dijalankan lewat pembentukan opini dan pandangan masyarakat atau warga lembaga pendidikan; (3) normative re educative. Norma adalah aturan yang berlaku di masyarakat. norma termasyarakatkan lewat pendidikan norma digandengkan dengan pendidikan ulang untuk menanamkan dan mengganti paradigma berpikir masyarakat lembaga yang lama dengan yang baru.

Pada strategi pertama tersebut dikembangkan melalui pendekatan perintah dan larangan atau reward and punishment. Sedangkan pada strategi kedua dan ketiga tersebut dikembangkan melalui pembiasaan, keteladanan, dan pendekatan persuasif atau mengajak kepada warganya dengan cara yang halus, dengan memberikan alasan dan prospek baik yang bisa meyakinkan mereka. Sifat kegiatannya bisa berupa aksi positif dan reaksi positif. Bisa pula berupa proaksi, yakni membuat aksi atas inisiatif sendiri, jenis dan arah ditentukan sendiri, tetapi membaca munculnya aksi-aksi agar dapat ikut memberi warna dan arah pada perkembangan. Bisa pula berupa antipasti, yakni tindakan aktif menciptakan situasi dan kondisi ideal agar tercapai tujuan idealnya

\section{KESIMPULAN}

FALASIFA, Vol. 9 Nomor 1 Maret 2018 | 65 
Siti Majidah

Berdasarkan pemaparan diatas, maka dapat disimpulkan bahwa budaya religius sekolah adalah upaya terwujudnya nilai-nilai ajaran agama sebagai tradisi dalam berperilaku dan budaya organisasi yang diikuti oleh seluruh warga di sekolah. Ada delapan landasan yang mendasari penciptaan budaya religius di sekolah. Budaya religius merupakan hal yang sangat penting dan harus diciptakan di lembaga pendidikan, karena lembaga pendidikan merupakan salah satu lembaga yang mentransformasikan nilai atau melakukan pendidikan nilai. Terdapat empat bentuk kegiatan yang dapat digunakan sebagai aplikasi penciptaan budaya religius. Sedangkan strategi membudayakan nilai-nilai religius di lembaga pendidikan dapat dilakukan melalui: (1) power strategi, (2) persuasive strategy, (3) normative re educative.

\section{DAFTAR PUSTAKA}

Al-Faruqi, Ismail Raji. Islamization of Knowledge, General Principles and Workplan. Washington DC : International institute of Islamic Thoungt, 1982.

Antliony, Darden Bedford. Sistem Pengendalan Manajemen, Jilid 1. Jakarta : Bina Rupa Aksara, 1992.

Asri, Budiningsih. Pembelajaran Moral Berpijak pada Karakteristik Siswa dan Budayanya. Jakarta : Rineka Cipta, 2004.

Asrori, Muhammad. Psikologi Pembelajaran. Bandung : Wacana Prima, 2007.

Azizy, A. Qodri. Pendidikan (Agama) untuk Membangun Etika Sosial. Semarang : Aneka Ilmu, 2002.

Baidhowi, Zakiyuddin. Pendidikan Agama Berwawasan Multikultural. Jakarta : Airlangga, 2005.

Brubacher, J.S. Modern Philoshophy of Education. New Delhi : Tata Mc. Grave Hill Publishing, t.t.

Departemen Pendidikan dan Kebudayaan. Kamus Besar Bahasa Indonesia. Jakarta : PT. Balai Pustaka, 1991.

Dhara, Talizhidu. Budaya Organises. Jakarta : Rinike Cipta, 1997.

Ekosusilo, Madyo. Hasil Penelitian Kualitatif Sekolah Unggul Berbasis Nilai (Studi Multi Kasus di SMA Negeri 1, SMA Regia Pacis dan SMA Al Islam 01 Surakarta). Sukoharjo : Univet Bantara Press, 2003.

Fajar, A. Malik. Holistika Pemikiran Pendidikan. Bandung : RajaGrafindo Persada, 2005.

Fernandez, SO. Citra Manusia Budaya Timur dan Barat. Kupang : Nusa Indah, 1990.

Purwanto. Budaya Perusahaan. Yogyakarta : Pustaka Pelajar, 1984.

66 | FaLASIFA, Vol. 9 Nomor 1 Maret 2018 
Hofstede, Geertz. Corperate Culture of Organization. London : Francs Pub, 1980.

Indrafchrudi, Soekarto. Bagaimana Mengakrabkan Sekolah dengan Orangtua Murid dan Masyarakat. Malang : IKIP Malang, 1994.

J.P. Kotter dan J.L. Heskett. Dampak Budaya Perusahaan Terbadap Kinerja, terj. Benyamin Molan. Jakarta : Prenhallindo, 1992.

. Dampak Budaya Perusabaan Terhadap Kinerja. Jakarta : PT Perhallindo,

1997.

Koentjaraningrat. Kebudayaan, Mentalitas dan Pembangunan. Jakarta : Gramedia, 1989

Muhaimin. Paradigma Pendidikan Islam. Bandung : Rosdakarya, 2001.

Pengembangan Kurikulum Pendidikan Agama Islam. Jakarta :

Raja Grafindo Persada, 2005.

Mulyasa. Manajemen Berbasis Sekolah. Bandung : Remaja Rosdakarya, 2007.

Ndara, Talizuhu. Teori Budaya Organisasi. Jakarta : Rineka Cipta, 2005.

Rahajo, Slamet. Memadu Sains dan Agama Menuju Universitas Masa Depan. Malang : UIN Malang, 2004.

Sahlan, Asmaun. Mewrijudkan Budaya Religius di Sekolah Upaya Mengembangkan PAI dari Teori ke Aksi. Malang : UIN Maliki Press, 2009.

Sumiati, Asra. Metode Pembelajaran. Bandung : CV Wacana Prima, 2007.

Tafsir, Ahmad Metodologi Pengajaran Agama Islam. Bandung : Remaja Rosda Karya, 2004.

Undang-undang Dasar 1945 dan Amandemennya. Bandung : Fokus Media, 2009.

Undang-Undang Nomor 20 Tahun 2003 tentang Sisdiknas. Jakarta: Depdiknas, 2003.

Yasin, A. Fatah. Dimensi-Dimensi Pendidikan Islam. Malang: UIN Malang Press, 2008 
Siti Majidah

68 | FALASIFA, Vol. 9 Nomor 1 Maret 2018 